\title{
Fungating breast mass in a developed country
}

\author{
Israel Ugalde, Daniela Pirela
}

Department of Internal Medicine, Mount Sinai Medical Center, Miami Beach, Florida, USA

\section{Correspondence to Dr Israel Ugalde, israel.ugalde@msmc.com}

Accepted 19 April 2018

\section{DESCRIPTION}

A 56-year-old woman presented to the emergency department with a left breast mass. Initially, she noticed two small lumps on the left breast that evolved in 18 months into an ulcerated mass with foul-odour drainage. Four months prior to admission, she developed fevers, fatigue and progressive dyspnoea. She normally could walk a block without limitations but progressed to dyspnoea with minimal exertion. Her family noted that she was spending most of the day in bed secondary to fatigue. Her fevers measured as high as $101.5^{\circ} \mathrm{F}$ and was alleviated by acetaminophen. One week prior to admission, she had a syncopal episode while standing up from her couch. Her mother came to visit after the syncope and noticed a foul odour. After she revealed the mass to her mother, she was taken to a primary care doctor who recommended the emergency department. The patient had no known medical history. She denied ever having a screening colonoscopy or mammography. She had no history of tobacco, hormone contraceptive or replacement use. Her paternal aunt and grandmother had breast cancer.

On physical examination, she initially presented with a heart rate of 112 beats per minute, respiratory rate of 18 breaths per minute and an oxygen saturation of $95 \%$ on $3 \mathrm{~L}$ nasal cannula. There was an ulcerative-necrotic left breast mass with violaceous skin changes (figure 1) along with palpable bilateral axillary and cervical lymphadenopathy. She had decreased breath sounds bilaterally with crackles noted on the right posterior base. CT imaging visualised bilateral peribronchovascular hypodense masses measuring up to $5.0 \times 4.7 \times 6.1 \mathrm{~cm}$ (figure 2A). It also noted a significant pleural effusion on the right and a distant L3 soft tissue mass (figure 2B). Core needle biopsy described

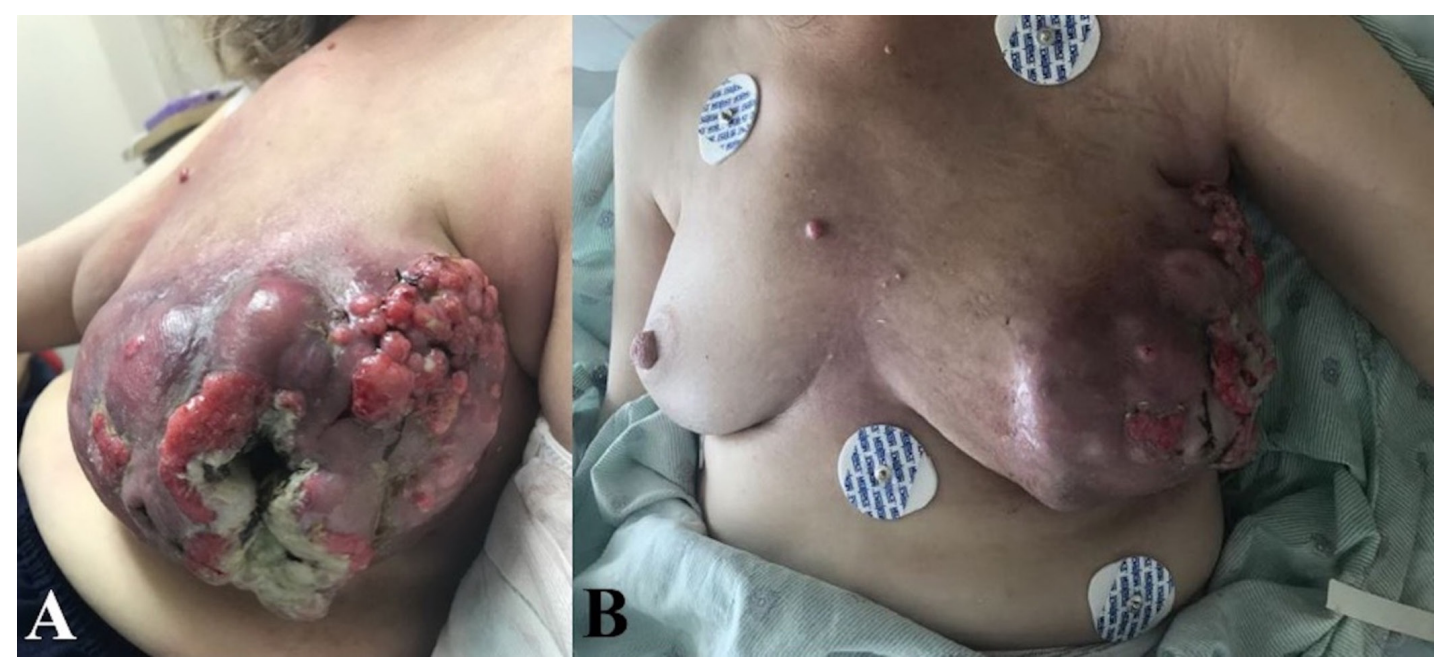

Figure 1 Lateral (A) and anterior (B) views of left fungating breast mass.

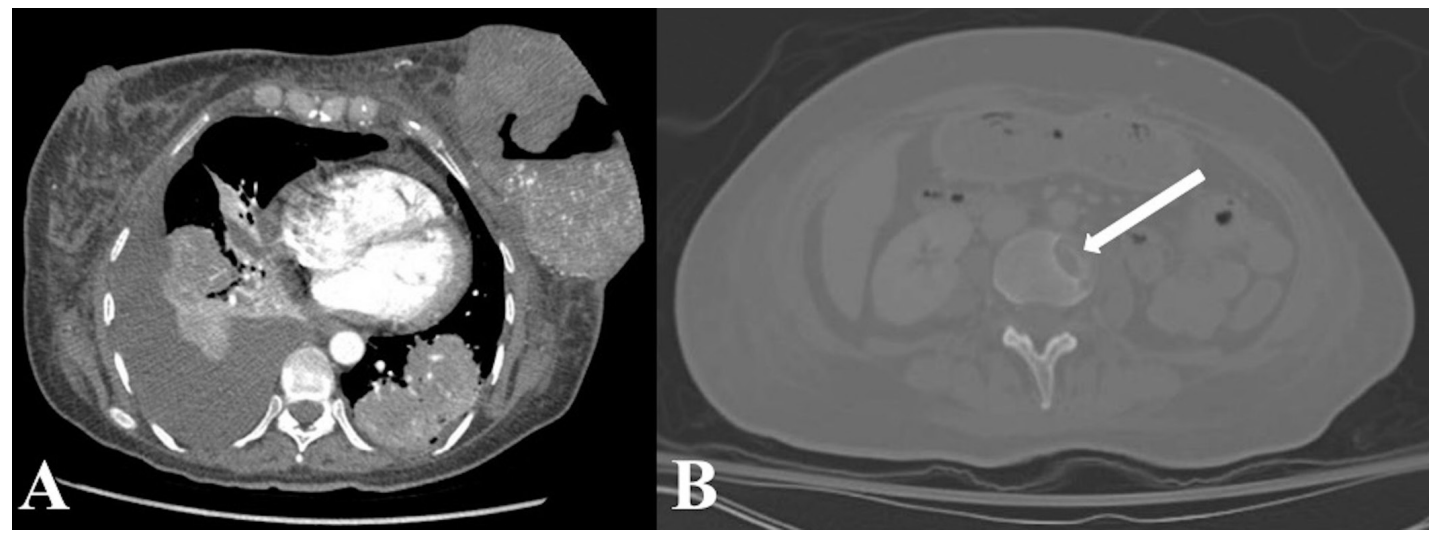

Figure 2 Axial CT of peribronchovascular hypodense masses with pleural effusion (A) and L3 soft tissue mass (B white arrow). 
oestrogen- receptor negative, progesterone-receptor positive, human epidermal growth factor receptor 2 (HER2)-positive infiltrating ductal carcinoma. The necrotic breast mass had a superimposed infection with Escherichia coli that was treated with piperacillin-tazobactam for 7 days. Her dyspnoea was alleviated after $1250 \mathrm{~mL}$ thoracentesis of the malignant effusion. After discussion with the surgical and medical oncologist, the patient was discharged for outpatient chemotherapy.

Infiltrating ductal carcinoma is the most common type of invasive breast cancer accounting for $73.5 \%$ of invasive disease cases in the USA. ${ }^{1}$ It has a $98.9 \%$ 5-year survival if diagnosed at a localised stage. ${ }^{1}$ The patient never sought out medical care for the breast mass out of financial concerns for the cost of diagnosis and treatment. Breast cancer screening is recommended starting at age 40 in select women and biennially in all women aged 50-74 years. Meta-analysis exhibits a 62\% relative

\section{Learning points}

- The benefit of screening mammography is most evident in patients aged $50-74$ years with a $24.1 \%-31.8 \%$ relative reduction in lifetime breast cancer mortality.

- Infiltrating ductal carcinoma is the most common type of invasive breast cancer.

- Female gender, age above 50 and a family history of breast cancer are the top three risk factors for the development of breast cancer. reduction of advanced breast cancer in patients over the age of 50 who participate in screening mammography. ${ }^{2}$ The overall benefit of screening mammography is most evident in patients aged $50-74$ years. There is a $24.1 \%-31.8 \%$ relative reduction in lifetime breast cancer mortality. ${ }^{2}$ This patient's advanced disease emphasises the importance of early diagnosis by screening and symptomatic presentation.

Contributors All authors have directly participated in the planning and execution of this case report in medicine. IU and DP were the internal medicine physicians responsible for the care of the patient during the hospitalisation. All authors contributed to the content and revision of the final manuscript. The figures were created by IU and he was responsible for explaining the consent to publish to the patient during her hospitalisation.

Funding The authors have not declared a specific grant for this research from any funding agency in the public, commercial or not-for-profit sectors.

Competing interests None declared.

Patient consent Obtained.

Provenance and peer review Not commissioned; externally peer reviewed.

(c) BMJ Publishing Group Ltd (unless otherwise stated in the text of the article) 2018. All rights reserved. No commercial use is permitted unless otherwise expressly granted.

\section{REFERENCES}

1 Howlader N, Noone A, Krapcho M, et al. SEER Cancer Statistics Review (CSR) 19752014. 2017 https://seer.cancer.gov/csr/1975_2014/

2 Siu AL. U.S. Preventive Services Task Force. Screening for Breast Cancer: U.S. Preventive Services Task Force Recommendation Statement. Ann Intern Med 2016;164:279-96.

3 Davidson NEBreast Cancer and Benign Breast Disorders [Internet]. Twenty Fif. Goldman-Cecil Medicine2016:1351-60 Elsevier Inc. http://www.sciencedirect.com/ science/article/pii/B9781455750177001987

Copyright 2018 BMJ Publishing Group. All rights reserved. For permission to reuse any of this content visit

http://group.bmj.com/group/rights-licensing/permissions.

BMJ Case Report Fellows may re-use this article for personal use and teaching without any further permission.

Become a Fellow of BMJ Case Reports today and you can:

- Submit as many cases as you like

- Enjoy fast sympathetic peer review and rapid publication of accepted articles

- Access all the published articles

Re-use any of the published material for personal use and teaching without further permission

For information on Institutional Fellowships contact consortiasales@bmjgroup.com

Visit casereports.bmj.com for more articles like this and to become a Fellow 